Article

\title{
Electrodeposition of Hydroxyapatite on a Metallic 3D-Woven Bioscaffold
}

\author{
Ju Xue ${ }^{1, *}$, Ashley Farris ${ }^{2}$, Yunfei Wang ${ }^{1}$, Weiyan Yeh ${ }^{1}$, Cristina Romany ${ }^{1}$, James K. Guest ${ }^{3,4}$, \\ Warren L. Grayson ${ }^{2}$, Anthony S. Hall ${ }^{1}$ and Timothy P. Weihs ${ }^{1,4, *}$ \\ 1 Department of Materials Science and Engineering, Johns Hopkins University, Baltimore, MD 21218, USA; \\ yunfeiwang93@jhu.edu (Y.F.W.); weiyen1995@gmail.com (W.Y.Y.); cromany1@jhu.edu (C.R.); \\ shoji@jhu.edu (A.S.H.) \\ 2 Department of Biomedical Engineering, Johns Hopkins University, Baltimore, MD 21218, USA; \\ afarris2@jhu.edu (A.F.); wgrayson@jhmi.edu (W.L.G.) \\ 3 Department of Civil and Systems Engineering, Johns Hopkins University, Baltimore, MD 21218, USA; \\ jkguest@jhu.edu \\ 4 Hopkins Extreme Materials Institute, Johns Hopkins University, Baltimore, MD 21218, USA \\ * Correspondence: jxue5@jhu.edu (J.X.); weihs@jhu.edu (T.P.W.)
}

Received: 11 May 2020; Accepted: 18 July 2020; Published: 23 July 2020

\begin{abstract}
In this study, we demonstrate that a uniform coating of hydroxyapatite ( $\left.\mathrm{HAp}, \mathrm{Ca}_{10}\left(\mathrm{PO}_{4}\right)_{6}(\mathrm{OH})_{2}\right)$ can be electrochemically deposited onto metallic 3D-woven bone scaffolds to enhance their bioactivity. The HAp coatings were deposited onto metallic scaffolds using an electrolyte containing $\mathrm{Ca}\left(\mathrm{NO}_{3}\right)_{2} \cdot 4 \mathrm{H}_{2} \mathrm{O}$, $\mathrm{NH}_{4} \mathrm{H}_{2} \mathrm{PO}_{4}$, and $\mathrm{NaNO}_{3}$. The deposition potential was varied to maximize the uniformity and adhesion of the coating. Using X-ray diffraction (XRD), Raman spectroscopy, and energy-dispersive spectroscopy (EDS), we found crystallized HAp on the 3D-woven lattice under all deposition potentials, while the $-1.5 \mathrm{~V}$ mercury sulfate reference electrode potential provided the best local uniformity with a satisfactory deposition rate. The coatings generated under this optimized condition were approximately $5 \mu \mathrm{m}$ thick and uniform throughout the internal and external sections of the woven lattice. We seeded and cultured both coated and uncoated scaffolds with human adipose-derived stromal/stem cells (ASCs) for $12 \mathrm{~h}$ and 4 days. We observed that the HAp coating increased the initial cell seeding efficiency by approximately $20 \%$. Furthermore, after 4 days of culture, ASCs cultured on HAp-coated stainless-steel scaffolds increased by $32 \%$ compared to only $17 \%$ on the uncoated scaffold. Together, these results suggest that the HAp coating improves cellular adhesion.
\end{abstract}

Keywords: hydroxyapatite; 3D-woven lattice; bioscaffolds; electrodeposition; bone engineering

\section{Introduction}

Designing and manufacturing metallic bioscaffolds to treat critical-sized or non-healing skeletal defects have drawn significant attention in the fields of tissue engineering [1,2] and regenerative medicine [3]. Researchers typically design bioscaffolds to meet the following design criteria: (i) The scaffold should possess proper surface functionalization to promote cell adhesion and growth [4], (ii) the architecture of the scaffold should permit sufficient penetration of nutrients, and transportation of gases and wastes [5], and (iii) the scaffold should include materials with sufficient biocompatibility [6,7]. While new materials are being explored [8], current materials for manufacturing bone replacement scaffolds typically include either biodegradable thermoplastic polymers or non-degradable metals.

The biodegradable polymers used to manufacture bone scaffolds include polylactic acid (PLLA), poly(lactide-co-glycolide) (PLGA), and polycaprolactone (PCL), and many studies have been conducted, particularly given the rapid rise in the three-dimensional printing (3DP) of porous polymeric scaffolds. 
However, these polymeric materials have two major limitations. Their elastic moduli are far lower than cancellous bone $[9,10]$, thereby limiting their efficacy in load-bearing tissues, and they degrade more slowly than the bone matrix remodels, which may result in device failure.

The most common metals used to manufacture nondegradable scaffolds are stainless steel (SS), titanium (Ti) alloys, and cobalt (Co) alloys due to their biocompatibility, resistance to corrosion, and adequate mechanical strength [11]. Techniques for manufacturing the porous metallic scaffold include additive manufacturing approaches such as laser beam powder bed (LBPB), wire-fed laser beam (WFLB), and selective laser sintering (SLS) [12-16]. While these techniques enable the fabrication of metallic scaffolds with complex external shapes and predefined internal lattices, the rapid solidification and directional cooling inherent to these techniques present challenges in controlling the microstructure and mechanical properties of the scaffold material [17-19]. Three-dimensional (3D) weaving using metallic wires with well-controlled microstructures and properties offers an attractive alternative, particularly given that weave stiffness, porosity, and permeability can be optimized to enhance bone growth. However, for all of these scaffolds, coatings are often needed to improve biocompatibility and cell growth.

A common approach to achieving functionalized porous, inert metallic scaffolds is to coat them with hydroxyapatite $\left(\mathrm{HAp}, \mathrm{Ca}_{10}\left(\mathrm{PO}_{4}\right)_{6}(\mathrm{OH})_{2}\right)$ [11]. The hybrid material adopts the superior mechanical integrity of the metal and the favorable biological features of HAp [20]. As a pure calcium phosphate phase, HAp is a common biomaterial in orthopedic and dental fields due to its osteoconductive and bioactive properties [21]. HAp coatings can enhance both cell seeding efficiency and proliferation by increasing the surface roughness and binding sites of the scaffolds [22,23]. Furthermore, HAp coatings can promote interfacial bonding between newly formed bone tissue and the implants; bone tissue will keep growing until it fills the porosity of the implants. This "mechanical interlocking" feature will increase the strength of the bond between the growing bone and the scaffold [20].

The conventional technique for coating metallic implants with HAp is plasma spraying [24]. Although studies show encouraging results for plasma-sprayed HAp coatings [25], some of the intrinsic features of this method remain concerning for tissue engineering applications. These include the presence of amorphous phases resulting from the extremely high process temperatures [26] and the difficulty of coating implants with complex geometrical features due to the line-of-sight nature of the process [27]. Alternative methods include: Sol-gel processing [28,29], biomimetic deposition [30-32], hydrothermal processing [33], electrophoresis [34], gas detonation deposition [35-37], and electrodeposition [38-40]. Among these, electrodeposition is the most promising technique because it can deposit homogeneous HAp coatings on interior and exterior surfaces of metallic scaffolds, regardless of a sample's size or pore geometry. Additionally, electrodeposition offers a higher degree of tailoring than plasma spraying; morphology and coating thickness can be modified in a controlled manner by varying the deposition parameters such as temperature, potential, and electrolyte. Successful synthesis of HAp coatings via the electrodeposition method has been reported for various porous substrates [41-44]. However, to date, there are no reports of HAp being electrodeposited onto 3D metallic weaves. To enhance our understanding and to improve the clinical relevance of electrodeposition, in this pilot study, we seek to electrochemically coat 3D-woven stainless-steel scaffolds with HAp. This proof-of-concept study will be followed by coating 3D-woven scaffolds that are fabricated with biodegradable $\mathrm{Mg}$ wires.

To conduct the study, we employed a three-dimensional (3D) weaving system $[45,46]$ to manufacture a woven lattice using stainless-steel wires. Guided by topology optimization, the pore structure and properties of the scaffolds, such as stiffness and fluid permeability [47-49], can be tailored by changing lattice architecture, wire diameter, and wire format (solid, hollow, or yarn) to promote cellular infiltration and bone regeneration [50,51]. To enhance biocompatibility, hydroxyapatite was electrodeposited onto the 3D-woven lattice using a customized three-electrode setup that promotes a more uniform electron field distribution, thus helping ion diffusion and aiding HAp nuclei deposition onto the wires' surfaces found within the woven lattice. Various deposition potentials were applied, 
and their effect on coating morphology, microstructure, and atomic ratio was explored. Once optimized, the effect of HAp coatings on adipose-derived stem cells (ASCs) adhesion and growth was evaluated.

\section{Materials and Methods}

\subsection{Fabrication of 3D-Woven Lattices and Sample Pretreatment}

We manufactured 3D-woven lattices with a standard architecture containing five layers of warp wires and six layers of fill wires (Figure 1a-d) with a semi-automated weaving machine (SAERTEX USA LLC, Huntersville, NC, USA). The wires were 304 stainless steel (304 SS) with diameters of $152 \mu \mathrm{m}$ in the $\mathrm{Z}$ direction and $202 \mu \mathrm{m}$ in the warp and fill directions, and the resulting weaves have a theoretical hydraulic diameter near $170 \mu \mathrm{m}$. (Note: While $316 \mathrm{~L}$ stainless steel is typically used for bioimplants, and biodegradable Mg wires will be used in our future in vivo studies, we utilized 304 SS wires that were available to fabricate a non-degradable substrate for this preliminary in vitro study). The fabricated weave measured $500 \times 36 \times 3.6 \mathrm{~mm}^{3}$ and was cut into $10 \times 10 \times 3.6 \mathrm{~mm}^{3}$ samples using a diamond wire saw. We then cleaned samples ultrasonically with a $\mathrm{NaOH}$ solution $(1 \mathrm{M})$, ethanol, and deionized water.
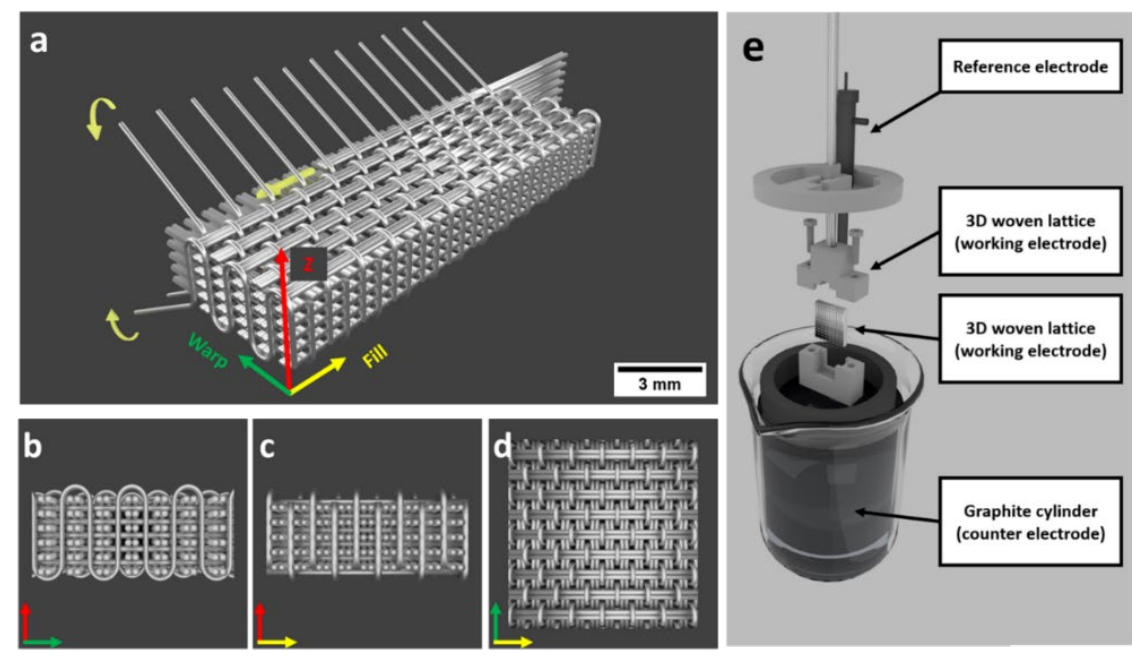

Figure 1. (a) A schematic of the 3D-woven lattice with warp, fill, and $Z$ wires woven in three orthogonal directions; (b) 2D view in fill direction; (c) 2D view in warp direction; (d) 2D view in Z direction; (e) a schematic of the modified 3D electrodeposition system consisting of a working electrode (3D-woven lattice), counter electrode (graphite cylinder), and a reference electrode $\left(\mathrm{Hg} / \mathrm{HgSO}_{4}\right)$.

\subsection{Synthesis of HAp Coatings}

Figure 1e shows the modified three-electrode electrodeposition setup that we designed and employed in this study. In order to ensure a more even distribution of the electric field, we nested the working electrode (woven lattice) and the mercury sulfate reference electrode (MSRE, filling solution: Saturated $\mathrm{K}_{2} \mathrm{SO}_{4}$ ) inside the counter-electrode (graphite cylinder). The graphite cylinder measured $57 \mathrm{~mm}$ in diameter and $80 \mathrm{~mm}$ in height. All the electrodes were submerged in $200 \mathrm{~mL}$ of electrolyte containing $15 \mathrm{mM} \mathrm{Ca}\left(\mathrm{NO}_{3}\right)_{2} \cdot 4 \mathrm{H}_{2} \mathrm{O}$ and $9 \mathrm{mM} \mathrm{NH}_{4} \mathrm{H}_{2} \mathrm{PO}_{4}$ with the $\mathrm{Ca} / \mathrm{P}$ ratio being 1.67 . To improve the conductivity of the electrolytes, $30 \mathrm{mM} \mathrm{NaNO}_{3}$ was added. This solution had a $\mathrm{pH}$ value of 4.8 when measured at $50^{\circ} \mathrm{C}$.

We used an Autolab PGSTAT204 potentiostat/galvanostat (Metrohm, Herisau, Switzerland) to perform linear sweep voltammetry and electrodeposition. We conducted the linear sweep voltammetry from an open-circuit potential (OCP) to $-2.0 \mathrm{~V}$ at a scan rate of $20 \mathrm{mV} / \mathrm{s}$. Then, three different potentials were chosen for the electrodeposition: $-1.3,-1.5$, and $-1.7 \mathrm{~V}$. We adjusted the duration of each trial to obtain a similar coating thickness: The higher the voltage, the shorter the duration. 
During these depositions, we kept the temperature constant at $50 \pm 0.2^{\circ} \mathrm{C}$ by utilizing a water bath (PolyScience, Niles, IL, USA). Instead of continuous electrodeposition, we programmed the system to alternate between $5 \mathrm{~min}$ of deposition at the selected potential and $5 \mathrm{~min}$ of non-deposition with a $0 \mathrm{~V}$ potential (Figure $2 \mathrm{~b}$ ) to allow ion refilling of the depletion layers throughout the 3D-woven lattice. As a result, the durations of deposition were 320,80 , and 64 min under a potential of $-1.3,-1.5$, and $-1.7 \mathrm{~V}$, respectively.
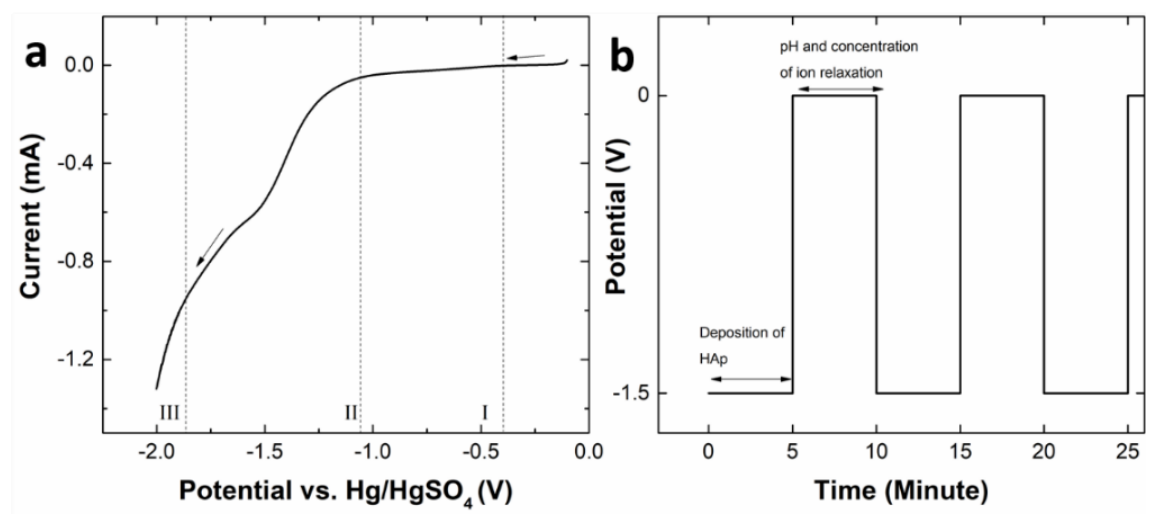

Figure 2. (a) Linear sweep voltammetry curve for hydroxyapatite (HAp) formation on stainless-steel (SS) 3D-woven lattice in an electrolyte containing $15 \mathrm{mM} \mathrm{Ca}\left(\mathrm{NO}_{3}\right)_{2} \cdot 4 \mathrm{H}_{2} \mathrm{O}, 9 \mathrm{mM} \mathrm{NH}_{4} \mathrm{H}_{2} \mathrm{PO}_{4}$, and $30 \mathrm{mM}$ $\mathrm{NaNO}_{3}$. The potential was swept from open-circuit potential (OCP) to $-2.0 \mathrm{~V}$, at a rate of $20 \mathrm{mV} / \mathrm{s}$ and a temperature of $50{ }^{\circ} \mathrm{C}$. (b) Schematic diagram of deposition waveforms used in the electrodeposition coating process.

After the deposition, we rinsed the samples thoroughly with distilled water to remove any residual electrolyte, and then air-dried them for $12 \mathrm{~h}$. To produce more material for crystallographic analysis via $\mathrm{X}$-ray diffraction, we repeated the same sample preparation and electrodeposition protocol on $10 \mathrm{~mm} \times 10 \mathrm{~mm} \times 1.5 \mathrm{~mm} 304 \mathrm{SS}$ plates. However, we first mechanically polished the plates with $\mathrm{SiC}$ sandpaper up to 1200 grit before cleaning.

\subsection{Characterization of the Deposited Coatings on 3D-Woven Lattice}

We studied the surface morphology and elemental composition of the HAp coatings deposited onto the woven samples using a scanning electron microscope (SEM) (Tescan Mira 3 GM, Brno, Czechia) equipped with energy-dispersive spectroscopy (EDS) (EDAX Inc., Mahwah, NJ, USA) on platinum-sputtered samples. We also employed Raman spectroscopy (micro-Raman setup and Horiba JY T64000 spectrometer, Kyoto, Japan) to identify the functional groups on the HAp coatings. The Raman spectra were obtained using an excitation wavelength of $514.5 \mathrm{~nm}$ with a laser power of $2 \mathrm{~mW}$. A pure HAp powder sample (Sigma-Aldrich, reagent grade) was used as the Raman reference. We characterized the crystal structure of the HAp coatings deposited onto 304 SS plates using symmetric $X$-ray diffraction (XRD) (Philips/PANalytical X'Pert Pro-MPD, Malvern, UK), Cu-K $\alpha$ radiation $(\lambda=1.5418 \AA$ ), a step size of $0.0033^{\circ}$, and a $2 \theta$ range from $10.0^{\circ}$ to $90.0^{\circ}$. We also obtained an XRD pattern for commercial HAp powders using the same diffraction parameters to serve as a reference.

To evaluate the HAp coating thickness distribution within the weave, we chose a sample with the optimal coating condition $(-1.5 \mathrm{~V})$ based on morphological and structural results. We cut the sample across its middle with a diamond wire saw to quantify the chemistry and thickness of coatings on the fill wires. We conducted energy-dispersive spectroscopy (EDS) to evaluate the elemental distribution of the coating, and we imaged each wire using a backscattered electron (BSE) detector to measure absolute coating thicknesses at 12 equally spaced points around each wire's perimeter. The position of the wires is registered based on a coordinate system detailed in Section 3.3. We measured 129 of 132 wires in this cross-section, excluding three wires that were lost during the cutting process. We then utilized 
the mean coating thickness measured for each individual fill wire to create a heatmap to visualize the coating uniformity within the weave. Specifically, the $X$ and $Y$-axis of the map correspond to the horizontal and vertical directions, and the color of the cell corresponds to the thickness of the HAp coating on the individual fill wires. The average fill wire coating thickness in both $X$ and $Y$ directions was also calculated and plotted. While a quantitative evaluation of the coating's bond strength will be performed in a future study, we do provide qualitative observations, as noted below.

\subsection{Cell Isolation and Culture}

We obtained adipose-derived stem cells (ASCs) from human subcutaneous adipose tissue in the form of lipoaspirate from one female Caucasian donor undergoing elective surgery, with written informed consent, and approval from the Institutional Review Board. We isolated ASCs as previously described [52]. Briefly, lipoaspirate was washed in phosphate-buffered saline, and tissue was digested for $1 \mathrm{~h}$ under agitation in a solution of collagenase type $\mathrm{I}(1 \mathrm{mg} / \mathrm{mL})$ and bovine serum albumin $(10 \mathrm{mg} / \mathrm{mL})$ diluted in phosphate-buffered saline (PBS) with calcium and magnesium. The stromal vascular fraction was obtained using differential centrifugation. We filtered the remaining cells through a $100 \mu \mathrm{m}$ cell strainer to remove large tissue aggregates. Red blood cells were lysed using a solution of ammonium chloride $(0.155 \mathrm{M})$, potassium bicarbonate $(0.01 \mathrm{M})$, and EDTA $(0.1 \mathrm{mM})$. We then plated the remaining cells onto tissue culture plastic and expanded them through two subsequent passages to enrich for ASCs. The expansion media consisted of Dulbecco's Modified Eagle Medium (Gibco, $4.5 \mathrm{~g} / \mathrm{L}$ of glucose) supplemented with 10\% fetal bovine serum (Atlanta Biologicals), $1 \%$ penicillin/streptomycin, and $1 \mathrm{ng} / \mathrm{mL}$ basic fibroblast growth factor-2 (FGF-2). Cells were trypsinized, suspended in stromal media (expansion media without FGF-2), and seeded onto the stainless-steel scaffolds dropwise in $20 \mu \mathrm{L}$ increments. We seeded a total of $100 \mu \mathrm{L}$ of cell suspension at a concentration of $20 \times 10^{6}$ cells $/ \mathrm{mL}$ onto both Hap-coated and -uncoated SS scaffolds, and we then incubated them for $30 \mathrm{~min}$ to promote adhesion. We subsequently added $5 \mathrm{~mL}$ of stromal media to completely cover all surfaces of the scaffolds.

After $12 \mathrm{~h}$ and 4 days of culture, we fixed cells in $4 \%$ paraformaldehyde for $20 \mathrm{~min}$ and stained them for nuclei and F-actin using 4',6-diamidino-2-phenylindole (DAPI) and phalloidin stains, respectively. Prior to staining, we blocked non-specific binding using 10\% fetal bovine serum in PBS for $30 \mathrm{~min}$ at room temperature. To stain, we diluted DAPI and phalloidin 1:2000 and 1:40 in 10\% fetal bovine serum in PBS, respectively. We then imaged samples using a Zeiss 510 Confocal microscope (Zeiss, Oberkochen, Germany) and the same fluorescence settings for each sample. Following $12 \mathrm{~h}$ or 4 days of culture, we measured DNA content as previously described using the Quant-IT PicoGreen dsDNA assay (Invitrogen, Carlsbad, CA, USA) according to the manufacturer instructions [53]. To determine cell attachment and proliferation following $12 \mathrm{~h}$ or 4 days of culture, we normalized DNA content on the scaffolds to the initial DNA content prior to seeding.

\section{Results and Discussion}

\subsection{Linear Sweep Voltammetry and Determination of the Deposition Potential}

In order to understand the effect of deposition potential, we performed linear sweep voltammetry (LSV) on the $304 \mathrm{SS}$ woven lattices in an electrolyte containing $15 \mathrm{mM} \mathrm{Ca}\left(\mathrm{NO}_{3}\right)_{2} \cdot 4 \mathrm{H}_{2} \mathrm{O}, 9 \mathrm{mM}$ $\mathrm{NH}_{4} \mathrm{H}_{2} \mathrm{PO}_{4}$, and $30 \mathrm{mM} \mathrm{NaNO}$. Figure 2a shows the LSV data, which are similar to data reported in [54]. As they note, a sequence of reactions is thought to occur as potential changes. When the applied potential is more negative than $-0.4 \mathrm{~V}$, the reduction of oxygen commences:

$$
\mathrm{O}_{2}+2 \mathrm{H}_{2} \mathrm{O}+4 \mathrm{e}^{-} \rightarrow 4 \mathrm{OH}_{\text {ads }}^{-}
$$


In the next stage ( -1.0 to $-1.85 \mathrm{~V})$, a further increase in the cathodic current is observed, and the following reactions are likely to happen:

$$
\begin{gathered}
\mathrm{H}_{2} \mathrm{PO}_{4}^{-} \rightarrow \mathrm{HPO}_{4}^{2-}+\mathrm{H}^{+} \\
\mathrm{HPO}_{4}^{2-} \rightarrow \mathrm{PO}_{4}^{3-}+\mathrm{H}^{+} \\
\mathrm{H}_{2} \mathrm{PO}_{4}^{-} \rightarrow \mathrm{PO}_{4}^{3-}+2 \mathrm{H}^{+} \\
2 \mathrm{H}^{+}+2 \mathrm{e}^{-} \rightarrow \mathrm{H}_{2} \uparrow \\
\mathrm{NO}_{3}^{-}+\mathrm{H}_{2} \mathrm{O}+2 \mathrm{e}^{-} \rightarrow \mathrm{NO}_{2}^{-}+2 \mathrm{OH}^{-}
\end{gathered}
$$

when the voltage drops below $-1.85 \mathrm{~V}$, a typical water reduction curve was observed with a rapid increase in the cathodic current, suggesting the following reaction:

$$
2 \mathrm{H}_{2} \mathrm{O}+2 \mathrm{e}^{-} \rightarrow \mathrm{H}_{2} \uparrow+2(\mathrm{OH})_{\text {ads }}^{-}
$$

To form HAp nuclei (Equation (8)), positive $\mathrm{Ca}^{2+}$ ions migrate to the working electrode and react with electrochemically formed $\mathrm{PO}_{4}^{3-}$ and $\mathrm{OH}^{-}$. The nuclei then adhere to the substrate, growing into coatings:

$$
10 \mathrm{Ca}^{2+}+6 \mathrm{PO}_{4}^{3-}+2 \mathrm{OH}^{-} \rightarrow \mathrm{Ca}_{10}\left(\mathrm{PO}_{4}\right)_{6}(\mathrm{OH})_{2}
$$

We chose three electrodeposition potentials for HAp deposition onto the woven SS lattices based on the analysis of the linear sweep voltammetry: $-1.3,-1.5$, and $-1.7 \mathrm{~V}$. We adjusted the duration of each deposition to 320,80 , and $65 \mathrm{~min}$, respectively, to obtain similar coating thicknesses in each case, and we performed all electrodepositions at $50{ }^{\circ} \mathrm{C}$ using alternating potentials, as shown in Figure $2 \mathrm{~b}$ for the $-1.5 \mathrm{~V}$ deposition.

\subsection{Coating Morphology and Microstructure}

Figure 3 presents SEM micrographs showing the typical morphology of the coatings deposited at $-1.3,-1.5$, and $-1.7 \mathrm{~V}$. Due to the low deposition rate at $-1.3 \mathrm{~V}$, uncoated areas are observed (Figure $3 \mathrm{~b}$ ) at low magnification. Figure $3 \mathrm{c}$ reveals, under high magnification, that the coatings are not compact and display an irregular plate-like morphology. This plate-like morphology is found in coatings generated under -1.5 and $-1.7 \mathrm{~V}$ (Figure $3 \mathrm{f}, \mathrm{i}$ ) as well. These plates typically measure $2-5 \mu \mathrm{m}$ in length with a submicron thickness. The coatings appear to be uniform and porous. The porosity increases the specific surface area of the 3D-woven lattices, as well as the surface area for cell adhesion [55]. A larger contact area should accelerate the healing of the damaged bone by increasing material transport between the implant and the surrounding tissue [56].

Coatings generated at $-1.7 \mathrm{~V}$ show mixed features (Figure 3g,h). In some areas, coatings display coral-like features; in other areas, no coating or only a partial coating is found. These features are thought to be caused by the high HAp deposition rate and interference from hydrogen bubbles forming on the lattice surface. Figure $3 i$ further reveals the impact of the hydrogen bubbles. In this figure, two distinct morphologies are found. On the right, plate-like HAp crystals consistent with those of the -1.3 and $-1.5 \mathrm{~V}$ samples are seen (Figure $3 \mathrm{c}, \mathrm{f})$. On the left, we observe finer plate-like crystals, which are widely considered to be freshly formed nuclei of the plate-like structure [57].

Coatings generated under $-1.5 \mathrm{~V}$ show the most promising features of the three potentials that we examined. The HAp coatings on the surface of the SS woven lattice are composed of irregular, plate-like crystals, providing a coating that is smooth on a macro-level yet rough and porous on a micro-level (Figure 3f). Furthermore, we do not observe evidence of the coral-like features that are attributed to hydrogen evolution as a result of rapid, non-uniform deposition. In contrast to $-1.7 \mathrm{~V}$, the coatings are uniform across the SS wires. 

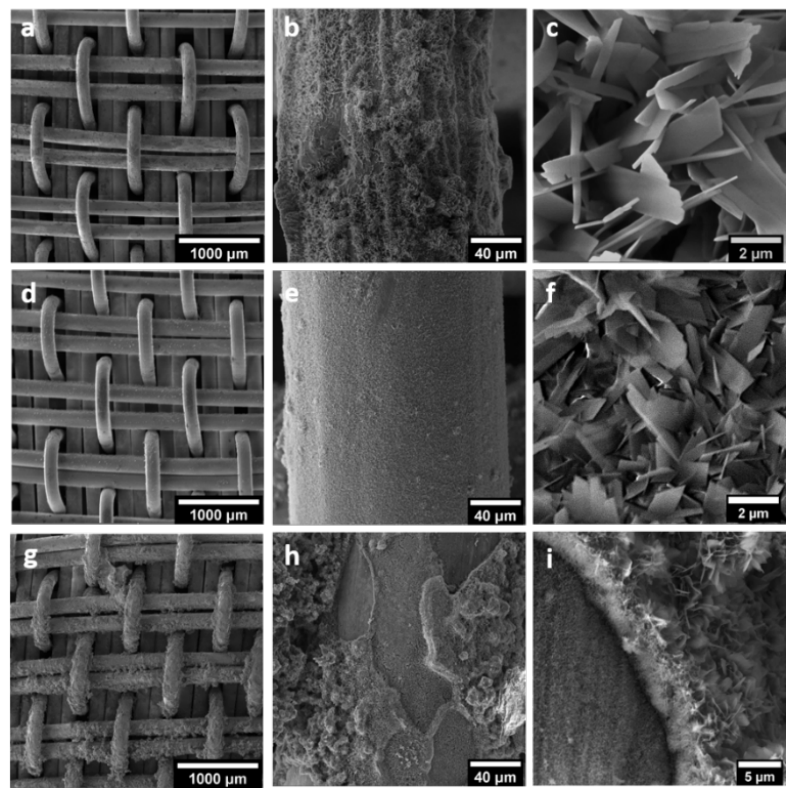

Figure 3. SEM micrographs showing the morphology of HAp formed on SS 3D-woven lattices under deposition potentials of $-1.3(\mathbf{a}-\mathbf{c}),-1.5(\mathbf{d}-\mathbf{f})$, and $-1.7 \mathrm{~V}(\mathbf{g}-\mathbf{i})$.

The $\mathrm{Ca} / \mathrm{P}$ atomic ratios obtained by EDS analysis are $1.69 \pm 0.06,1.67 \pm 0.06$, and $1.73 \pm 0.08$ for HAp coatings electrodeposited under $-1.3,-1.5$, and $-1.7 \mathrm{~V}$ potentials, respectively. These ratios are very close to the stoichiometric value of hydroxyapatite, 1.67. Previous studies [40] note the importance of the $\mathrm{Ca} / \mathrm{P}$ ratio as it is considered to be critical for the chemical stability of HAp. The typical EDS spectra of coatings generated under different electrodeposition potentials are also plotted and detailed in Appendix A, (Figure A1). The Raman spectra collected from the three deposited coatings (Figure 4) show nearly identical profiles compared to the pure HAp powder reference. In addition, most of the Raman bands correspond to the stretching mode of $\mathrm{PO}_{4}^{3-}\left(\mathrm{V}_{2}: 443\right.$ and $447 \mathrm{~cm}^{-1} ; \mathrm{V}_{4}: 582,594$, 610, and $620 \mathrm{~cm}^{-1} ; \mathrm{V}_{1}: 961 \mathrm{~cm}^{-1} ; \mathrm{V}_{3}: 1030,1046,1054$, and $1076 \mathrm{~cm}^{-1}$ ) [58]. No obvious shifts in the Raman band positions were observed from sample to sample, and the position of the Raman bands indicate that the coatings are primarily hydroxyapatite. There also exists a broad low-intensity peak at $1010 \mathrm{~cm}^{-1}$ and a narrow low-intensity peak at $1125 \mathrm{~cm}^{-1}$. A possible explanation for these low-intensity peaks is the existence of other calcium phosphate phases formed during the deposition process. Specifically, the $1025 \mathrm{~cm}^{-1}$ peak has been associated with a stretching mode of the $\mathrm{HPO}_{4}^{2-}$ group $\left(V_{3}: 1121 \mathrm{~cm}^{-1}\right)$ in dicalcium phosphate dihydrate (DCPD), and the $1010 \mathrm{~cm}^{-1}$ peak has been associated with a stretching mode of the $\mathrm{HPO}_{4}^{2-}$ group $\left(\mathrm{V}_{1}: 1010 \mathrm{~cm}^{-1}\right)$ in octacalcium phosphate (OCP) [58,59]. Interestingly, the relative peak intensity of the broad $1010 \mathrm{~cm}^{-1}$ peak increases as the deposition potential decreases. One explanation is that lower deposition potentials may yield lower local $\mathrm{pH}$, which favors the formation of the OCP more than HAp. Therefore, an increase in the volume of OCP could result when the deposition potential decreases [60]. However, the $\mathrm{Ca} / \mathrm{P}$ ratio of the coatings is significantly larger than those of OCP (1.33) and DCPD (1.00), and it very similar to HAp. Therefore, we conclude that the coatings generated under different deposition potentials are still mainly HAp with a limited amount of OCP and/or DCPD.

Figure 5 shows the X-ray diffraction patterns of coatings deposited onto SS plates. All peaks not associated with SS can be assigned to the most intense crystalline planes of HAp based on the XRD pattern of the HAp reference powder and the standard powder diffraction files (JCPDS, PDF\#01-072-1243). The strong peaks at $2 \theta=25.9^{\circ}, 31.8^{\circ}$, and $32.2^{\circ}$ correspond to the (002), (211), and (112) planes. The unusually strong peak at $25.9^{\circ}$ for the coatings compared to the reference HAp powders indicates that the HAp crystals grow in the preferred direction of [002] during the electrodepositions. This corresponds to the crystals growing with their $c$-axis perpendicular to the 
electrode surface, as reported in earlier electrodepositions [61-64]. Coatings deposited at potentials of -1.3 and $-1.7 \mathrm{~V}$ generate broad peaks with relatively low intensities from around $31^{\circ}$ to $33^{\circ}$. This is indicative of a thin coating and/or fine crystals, which could be due to the low deposition rate at $-1.3 \mathrm{~V}$ and the interference of hydrogen bubble formation at $-1.7 \mathrm{~V}$, respectively. The coatings deposited at $-1.5 \mathrm{~V}$ are stronger and sharper, indicating thicker films and/or larger crystals. Overall, the XRD results suggest that the coatings deposited onto the 3D SS woven lattice under similar deposition conditions as the SS plates samples will also contain crystallized HAp.

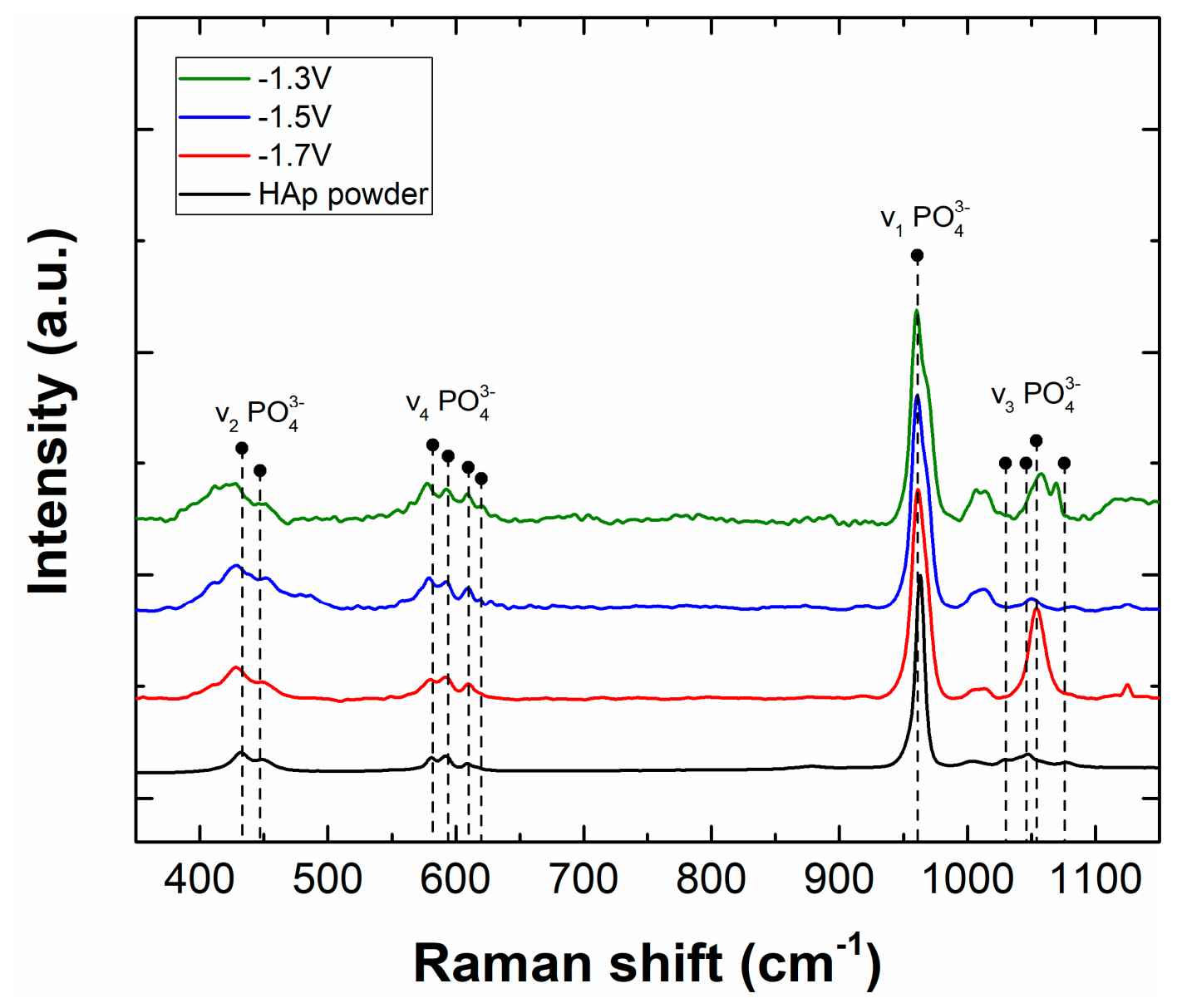

Figure 4. Raman spectra of HAp powders and HAp coatings deposited onto SS 3D-woven lattices under different electrodeposition potentials.

\subsection{HAp Coating Thickness and Chemistry}

The cross-sectional SEM images in Figure $6 \mathrm{a}, \mathrm{b}$ show a uniform HAp coating adhering to the wires following deposition at $-1.5 \mathrm{~V}$. Porosity is observed in the coating and corresponds to the surface morphology seen in Figure 3. The absence of delamination from the wires or crack along the wire/coating interface, particularly after mechanical polishing of the sample, suggests that the adhesion of the coating to the wires is strong. The EDS analysis shows a uniform distribution of calcium and phosphorus in the coatings.

A heatmap (Figure $7 \mathrm{~b}$ ) was created to visualize the measured HAp coating thickness on fill wires on one cross-section from a sample electrodeposited at $-1.5 \mathrm{~V}$. The $\mathrm{X}$ - and $Y$-axis of the map correspond to the horizontal and vertical directions, and the color of the cell corresponds to the thickness of the HAp coating of each fill wire. Three wires, labeled as " $\mathrm{M}$ " in the heatmap, were lost during cutting of the sample. The heatmap reveals a relatively uniform coating of the fill wires across the woven lattice with some variation in small areas such as (Y2-Y5, X1-X4). The defects are likely caused by hydrogen bubbles trapped within the weave during the deposition process, causing some of the wires to receive 
more coating than others. The fill coating thicknesses were averaged in the vertical $(Y)$ and horizontal $(X)$ directions and are plotted in Figure $7 \mathrm{c}, \mathrm{d}$. These plots suggest that both directions have a relatively uniform coating, and overall, there are no significant differences in coating thickness between the internal and the external sections of the woven lattice. Such uniformity of the HAp coatings is critical for applications involving porous metallic substrates.

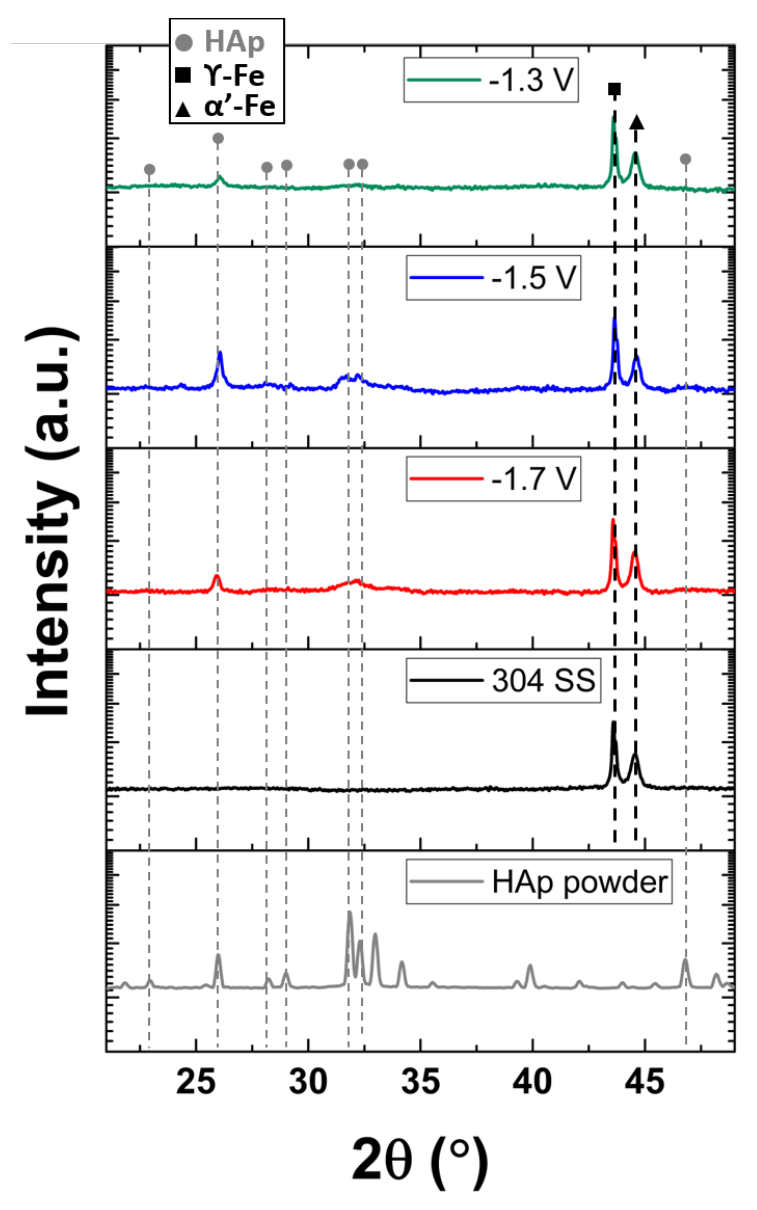

Figure 5. X-ray diffraction patterns of HAp coatings deposited onto 304 SS plates under different electrodeposition potentials, a bare 304 SS plate, and the HAp powders. The intensity ( $Y$-axis) is plotted using a logarithmic scale.
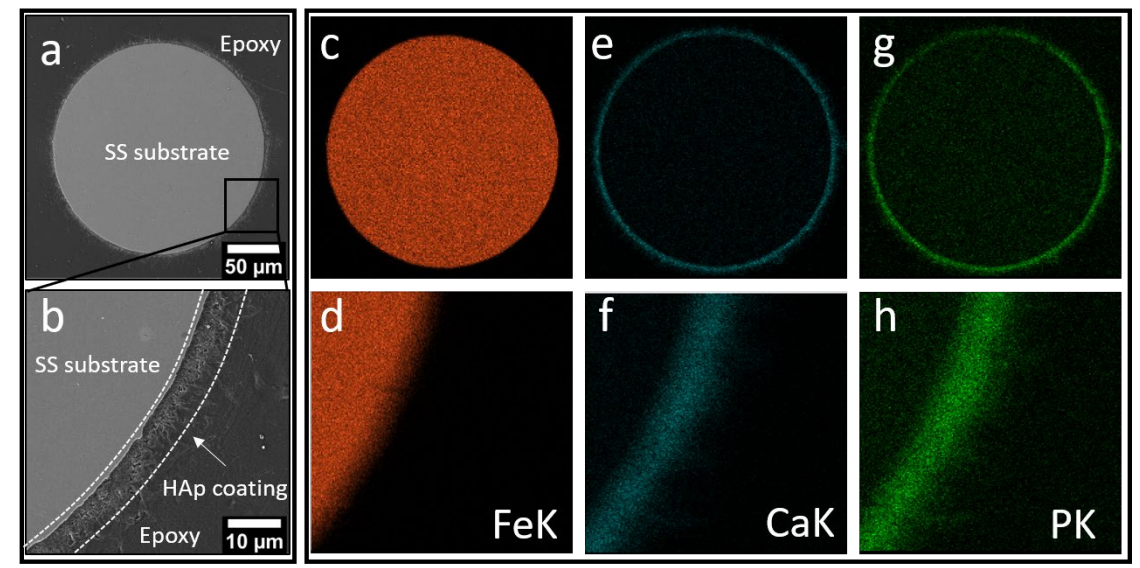

Figure 6. SEM micrographs and EDS analysis of HAp coatings synthesized under $-1.5 \mathrm{~V}$ on a 304 SS woven lattice. Cross-sectional morphologies: $(\mathbf{a}, \mathbf{b})$; elemental distribution of HAp coating: Iron: (c,d); calcium: (e,f); phosphorus: (g,h). 

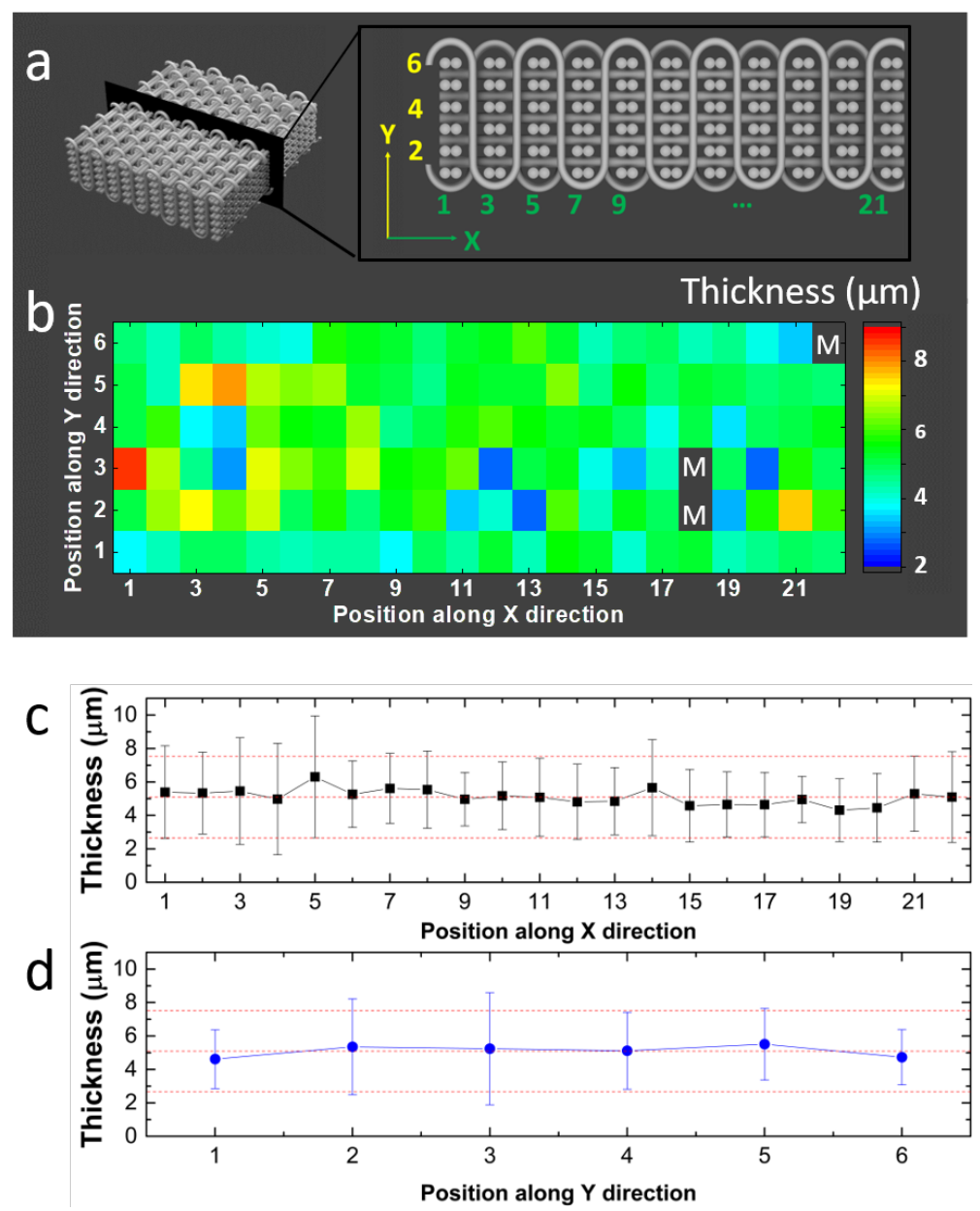

Figure 7. Coating thickness distribution on fill wires. (a) A schematic of a cross-sectional slice; (b) a coating thickness heatmap for the cross-section showing average coating thicknesses on individual fill wires as a function of location. $\mathrm{M}=$ missing wires; (c) coating thickness plotted along the horizontal direction (mean $\pm \mathrm{SD}$ ); (d) coating thickness plotted along the vertical direction. Red dashed line = global average and one standard deviation of all HAp coating thickness measurements (mean \pm SD).

Lastly, the average thickness of coatings is $5.1 \mu \mathrm{m}$, corresponding to a deposition rate of $0.0625 \mu \mathrm{m} / \mathrm{min}$. While other methods such as plasma spray or gas detonation deposition allow a much higher deposition rate (for example, the deposition rate of gas detonation can reach $10 \mu \mathrm{m} / \mathrm{s}$ [35]), the "line-of-sight" nature of these processes limit their application on 3D porous scaffolds. The electrodeposition method, on the other hand, enables uniform coating throughout a porous structure. The downside is a much lower electrodepositing rate that typically ranges from 0.05 to $0.3 \mu \mathrm{m} / \mathrm{min}$ [39]. In this study, the relatively low deposition rate can also be attributed to the alternating voltage pattern that we employed to ensure a uniform electrolyte concentration throughout the scaffold. In the future, we will try to optimize the deposition rate by altering the deposition temperature and electrolyte concentration.

\subsection{In Vitro Biocompatibility Analysis}

After culturing ASCs on the surface of coated and uncoated HAp scaffolds for 4 days, we observed that cells are able to adhere to the surface of the scaffolds. Additionally, actin filaments can be seen stretching across the pores of the woven scaffolds in both coated and uncoated groups (Figure 8). However, fluorescence images could not be obtained throughout the scaffolds, due to the opacity of the metallic scaffolds. Furthermore, the hardness of the wires relative to the cells prevents sectioning. 

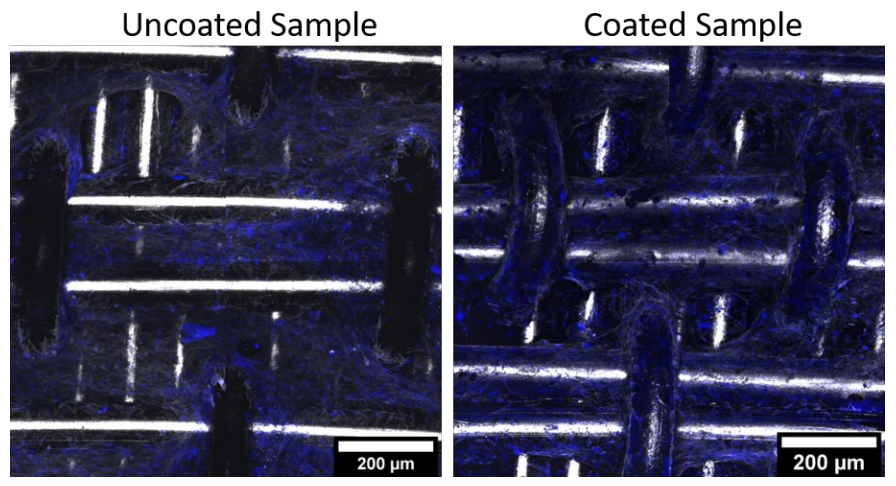

Figure 8. DAPI and phalloidin stains on uncoated and Hap-coated SS woven lattices after 4 days.

To quantify the effect of the HAp coating on both cellular adhesion and proliferation, ASCs were seeded on scaffolds and cultured for $12 \mathrm{~h}$ and 4 days. The $12 \mathrm{~h}$ time scale allows cells the opportunity to adhere to the surface without providing significant time to proliferate. After normalizing to the initial DNA seeded on each group, we observed that the HAp coating increases initial cell seeding efficiency by approximately $20 \%$. Furthermore, after 4 days of culture, ASCs cultured on HAp-coated stainless-steel scaffolds had increased by $32 \%$, whereas ASCs on the uncoated proliferated only $17 \%$ (Figure 9). Together, these results suggest that coating stainless-steel scaffolds with HAp using electrodeposition can improve cellular adhesion.

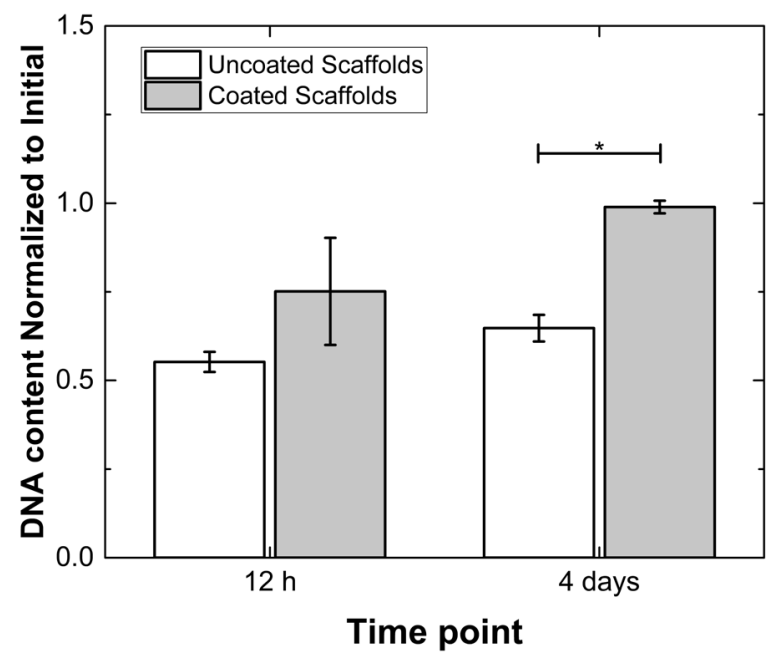

Figure 9. DNA content comparison between uncoated and Hap-coated SS woven lattice after culturing for $12 \mathrm{~h}$ and four days ( $n=3$ samples per group at each time point), (mean $\pm \mathrm{SE}$ ); significance determined by two-tailed Student's $t$-test, $p=0.0026$.

\section{Conclusions}

In summary, HAp coatings with nearly ideal $\mathrm{Ca} / \mathrm{P}$ atomic ratios were deposited onto 3D-woven SS lattices with a customized electrodeposition setup. We determined an optimal potential of $-1.5 \mathrm{~V}$ for electrodeposition at $50{ }^{\circ} \mathrm{C}$ within an electrolyte containing $15 \mathrm{mM} \mathrm{Ca}\left(\mathrm{NO}_{3}\right)_{2} \cdot 4 \mathrm{H}_{2} \mathrm{O}, 9 \mathrm{mM} \mathrm{NH}_{4} \mathrm{H}_{2} \mathrm{PO}_{4}$, and $30 \mathrm{mM} \mathrm{NaNO}$. A higher potential of $-1.7 \mathrm{~V}$ appears to generate hydrogen bubbles, causing noticeable damage to the coating, while a lower deposition potential of $-1.3 \mathrm{~V}$ yields a low deposition rate and uneven coatings. The optimized HAp coatings are relatively uniform in thickness throughout the interior of the porous SS weaves and contain sub-micron-scale HAp crystals. The finely structured coatings improve the bioactivity of the scaffold in short-term cell interaction studies. 
Author Contributions: Conceptualization, J.X. and T.W.; methodology, J.X., A.F., Y.W., W.Y., and C.R.; writing-original draft preparation, J.X., A.F., and Y.W.; writing—review and editing, J.G., W.G., A.H., and T.W. All authors have read and agreed to the published version of the manuscript

Funding: This research received funding from National Science Foundation [Award Abstract\#1538367], the Wilmer Imaging and Microscopy Core Grant [P30-EY001765].

Acknowledgments: The authors would like to thank Nicholas $\mathrm{Ng}$ and Tyrel McQueen for assistance in X-ray powder diffraction. The authors would like to thank. Natalia Drichko and Yuanyuan Xu from Raman Scattering Users Center at Johns Hopkins University for their help in Raman Spectroscopy.

Conflicts of Interest: The authors declare no conflict of interest.

\section{Appendix A}

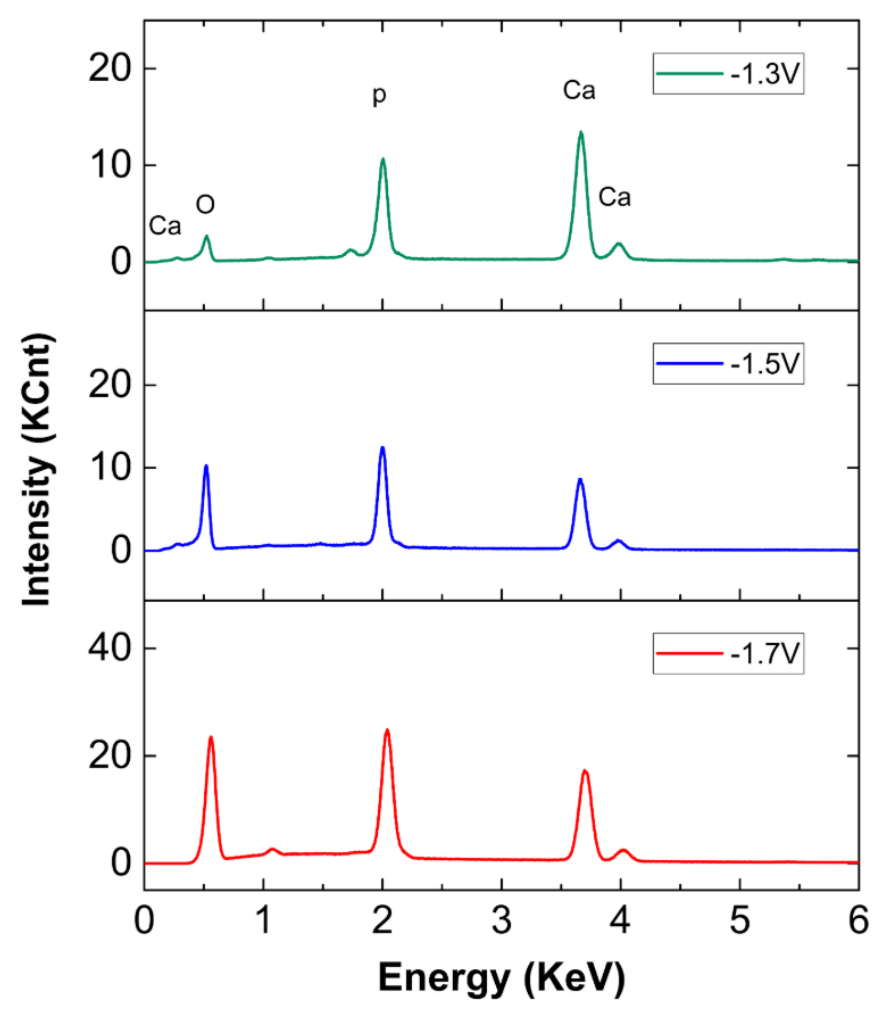

Figure A1. Typical EDS spectra of HAp coatings deposited on the weave under different electrodeposition potentials.

\section{References}

1. Amini, A.R.; Laurencin, C.T.; Nukavarapu, S.P. Bone tissue engineering: Recent advances and challenges. Crit. Rev. Biomed. Eng. 2012, 40,363-408. [CrossRef] [PubMed]

2. Alvarez, K.; Nakajima, H. Metallic Scaffolds for Bone Regeneration. Materials 2009, 2, 790-832. [CrossRef]

3. Guoping, C.; Takashi, U.; Tetsuya, T. Scaffold Design for Tissue Engineering. Macromol. Biosci. 2002, 2, 67-77. [CrossRef]

4. Dhandayuthapani, B.; Yoshida, Y.; Maekawa, T.; Kumar, D.S. Polymeric Scaffolds in Tissue Engineering Application: A Review. Int. J. Polym. Sci. 2011, 2011, 290602. [CrossRef]

5. Chan, B.P.; Leong, K.W. Scaffolding in tissue engineering: General approaches and tissue-specific considerations. Eur. Spine J. 2008, 17, 467-479. [CrossRef] [PubMed]

6. Risbud, M.V.; Sittinger, M. Tissue engineering: Advances in in vitro cartilage generation. Trends Biotechnol. 2002, 20, 351-356. [CrossRef]

7. Langer, R.; Tirrell, D.A. Designing materials for biology and medicine. Nature 2004, 428, 487-492. [CrossRef]

8. Staiger, M.; Pietak, A.; Huadmai, J.; Dias, G. Magnesium and its alloys as orthopedic biomaterials: A review. Biomaterials 2006, 27, 1728-1734. [CrossRef] 
9. Nyberg, E.L.; Farris, A.L.; Hung, B.P.; Dias, M.; Garcia, J.R.; Dorafshar, A.H.; Grayson, W.L. 3D-Printing Technologies for Craniofacial Rehabilitation, Reconstruction, and Regeneration. Ann. Biomed. Eng. 2016, 45, 45-57. [CrossRef]

10. Hollister, S.; Lin, C.; Saito, E.; Schek, R.; Taboas, J.; Williams, J.; Partee, B.; Flanagan, C.; Diggs, A.; Wilke, E.; et al. Engineering craniofacial scaffolds. Orthod. Craniofacial Res. 2005, 8, 162-173. [CrossRef]

11. Long, M.; Rack, H. Titanium alloys in total joint replacement-A materials science perspective. Biomaterials 1998, 19, 1621-1639. [CrossRef]

12. Kruth, J.-P.; Mercelis, P.; Van Vaerenbergh, J.; Froyen, L.; Rombouts, M. Binding mechanisms in selective laser sintering and selective laser melting. Rapid Prototyp. J. 2005, 11, 26-36. [CrossRef]

13. Bose, S.; Vahabzadeh, S.; Bandyopadhyay, A. Bone tissue engineering using 3D printing. Mater. Today 2013, 16, 496-504. [CrossRef]

14. Murr, L.; Gaytan, S.M.; Medina, F.; Lopez, H.; Martinez, E.; Machado, B.I.; Hernandez, D.H.; Lopez, M.I.; Wicker, R.B.; Bracke, J. Next-generation biomedical implants using additive manufacturing of complex, cellular and functional mesh arrays. Philos. Trans. R. Soc. A Math. Phys. Eng. Sci. 2010, 368, 1999-2032. [CrossRef] [PubMed]

15. Hollister, S. Erratum: Porous scaffold design for tissue engineering. Nat. Mater. 2006, 5, 590. [CrossRef]

16. Van Bael, S.; Kerckhofs, G.; Moesen, M.; Pyka, G.; Schrooten, J.; Kruth, J. Micro-CT-based improvement of geometrical and mechanical controllability of selective laser melted Ti6Al4V porous structures. Mater. Sci. Eng. A 2011, 528, 7423-7431. [CrossRef]

17. Zheng, B.; Zhou, Y.; Smugeresky, J.; Schoenung, J.; Lavernia, E. Thermal Behavior and Microstructure Evolution during Laser Deposition with Laser-Engineered Net Shaping: Part II. Experimental Investigation and Discussion. Met. Mater. Trans. A 2008, 39, 2237-2245. [CrossRef]

18. Cole, J.H.; Van Der Meulen, M.C.H. Whole Bone Mechanics and Bone Quality. Clin. Orthop. Relat. Res. 2011, 469, 2139-2149. [CrossRef]

19. Frazier, W.E. Metal Additive Manufacturing: A Review. J. Mater. Eng. Perform. 2014, 23, 1917-1928. [CrossRef]

20. Habibovic, P.; Li, J.; Van Der Valk, C.M.; Meijer, G.; Layrolle, P.; Van Blitterswijk, C.; De Groot, K. Biological performance of uncoated and octacalcium phosphate-coated Ti6Al4V. Biomaterials 2005, 26, 23-36. [CrossRef]

21. O’Brien, F.J. Biomaterials \& scaffolds for tissue engineering. Mater. Today 2011, 14, 88-95. [CrossRef]

22. Tapsir, Z.; Jamaludin, F.H.; Pingguan-Murphy, B.; Saidin, S. Immobilisation of hydroxyapatite-collagen on polydopamine grafted stainless steel 316L: Coating adhesion and in vitro cells evaluation. J. Biomater. Appl. 2017, 32, 987-995. [CrossRef] [PubMed]

23. Yoon, B.-J.V.; Xavier, F.; Walker, B.R.; Grinberg, S.; Cammisa, F.P.; Abjornson, C. Optimizing surface characteristics for cell adhesion and proliferation on titanium plasma spray coatings on polyetheretherketone. Spine J. 2016, 16, 1238-1243. [CrossRef] [PubMed]

24. De Groot, K.; Geesink, R.; Klein, C.P.A.T.; Serekian, P. Plasma sprayed coatings of hydroxylapatite. J. Biomed. Mater. Res. 1987, 21, 1375-1381. [CrossRef] [PubMed]

25. Mohseni, E.; Zalnezhad, E.; Razak, B.A. Comparative investigation on the adhesion of hydroxyapatite coating on Ti-6Al-4V implant: A review paper. Int. J. Adhes. Adhes. 2014, 48, 238-257. [CrossRef]

26. Ji, H.; Ponton, C.B.; Marquis, P.M. Microstructural characterization of hydroxyapatite coating on titanium. J. Mater. Sci. Mater. Electron. 1992, 3, 283-287. [CrossRef]

27. Huang, H.; Lan, P.-H.; Zhang, Y.-Q.; Li, X.-K.; Zhang, X.; Yuan, C.-F.; Zheng, X.-B.; Guo, Z. Surface characterization and in vivo performance of plasma-sprayed hydroxyapatite-coated porous Ti6Al4V implants generated by electron beam melting. Surf. Coat. Technol. 2015, 283, 80-88. [CrossRef]

28. Weng, W.; Baptista, J.L. Preparation and Characterization of Hydroxyapatite Coatings on Ti6Al4V Alloy by a Sol-Gel Method. J. Am. Ceram. Soc. 2004, 82, 27-32. [CrossRef]

29. Piveteau, L.-D.; Moner-Girona, M.; Schlapbach, L.; Barboux, P.; Boilot, J.-P.; Gasser, B. Thin films of calcium phosphate and titanium dioxide by a sol-gel route: A new method for coating medical implants. J. Mater. Sci. Mater. Electron. 1999, 10, 161-167. [CrossRef]

30. Chen, C.; Lee, I.-S.; Zhang, S.; Yang, H.C. Biomimetic apatite formation on calcium phosphate-coated titanium in Dulbecco's phosphate-buffered saline solution containing $\mathrm{CaCl} 2$ with and without fibronectin. Acta Biomater. 2010, 6, 2274-2281. [CrossRef] [PubMed] 
31. Yang, G.-L.; He, F.-M.; Hu, J.-A.; Wang, X.-X.; Zhao, S.-F. Effects of biomimetically and electrochemically deposited nano-hydroxyapatite coatings on osseointegration of porous titanium implants. Oral Surg. Oral Med. Oral Pathol. Oral Radiol. Endodontol. 2009, 107, 782-789. [CrossRef] [PubMed]

32. Stevanović, M.; Djošić, M.; Janković, A.; Kojić, V.; Vukašinović-Sekulić, M.; Stojanović, J.; Odović, J.; Sakač, M.C.; Yop, R.K.; Mišković-Stanković, V.; et al. Antibacterial graphene-based hydroxyapatite/chitosan coating with gentamicin for potential applications in bone tissue engineering. J. Biomed. Mater. Res. Part A 2020. [CrossRef]

33. Okido, M. Hydroxyapatite coating on titanium by means of thermal substrate method in aqueous solutions. Solid State Ionics 2002, 151, 47-52. [CrossRef]

34. Gottlander, M.; Johansson, C.B.; Wennerberg, A.; Albrektsson, T.; Radin, S.; Ducheyne, P. Bone tissue reactions to an electrophoretically applied calcium phosphate coating. Biomaterials 1997, 18, 551-557. [CrossRef]

35. Klyui, N.I.; Temchenko, V.P.; Gryshkov, A.P.; Dubok, V.A.; Shynkaruk, A.V.; Lyashenko, B.A.; Barynov, S.M. Properties of the hydroxyapatite coatings, obtained by gas-detonation deposition onto titanium substrates. Funct. Mater. 2011, 18, 285-292.

36. Strutynska, N.; Zatovsky, I.; Slobodyanik, N.; Malyshenko, A.; Prylutskyy, Y.; Prymak, O.; Vorona, I.; Ishchenko, S.; Baran, N.; Byeda, O.; et al. Preparation, Characterization, and Thermal Transformation of Poorly Crystalline Sodium- and Carbonate-Substituted Calcium Phosphate. Eur. J. Inorg. Chem. 2015, 2015, 622-629. [CrossRef]

37. Nosenko, V.; Strutynska, N.; Vorona, I.; Zatovsky, I.; Dzhagan, V.M.; Lemishko, S.V.; Epple, M.; Prymak, O.; Baran, N.; Ishchenko, S.; et al. Structure of Biocompatible Coatings Produced from Hydroxyapatite Nanoparticles by Detonation Spraying. Nanoscale Res. Lett. 2015, 10, 464. [CrossRef]

38. Chai, Y.C.; Truscello, S.; Van Bael, S.; Luyten, F.P.; Vleugels, J.; Schrooten, J. Perfusion electrodeposition of calcium phosphate on additive manufactured titanium scaffolds for bone engineering. Acta Biomater. 2011, 7 , 2310-2319. [CrossRef]

39. Dinh, T.M.T.; Nguyen, T.T.; Pham, T.N.; Nguyen, T.P.; Hoang, T.; Grossin, D.; Bertrand, G.; Drouet, C. Electrodeposition of HAp coatings on Ti6Al4V alloy and its electrochemical behavior in simulated body fluid solution. Adv. Nat. Sci. Nanosci. Nanotechnol. 2016, 7, 25008. [CrossRef]

40. Manso-Silván, M. Electrodeposition of hydroxyapatite coatings in basic conditions. Biomaterials 2000, 21, 1755-1761. [CrossRef]

41. Sun, X.; Lin, H.; Zhang, C.; Jin, J.; Di, S. Electrochemical Studies on CaP Electrodeposition on Titanium Scaffold. Coatings 2019, 9, 667. [CrossRef]

42. Wang, D.-X.; He, Y.; Bi, L.; Qu, Z.-H.; Zou, J.-W.; Pan, Z.; Fan, J.-J.; Chen, L.; Dong, X.; Liu, X.-N.; et al. Enhancing the bioactivity of Poly(lactic-co-glycolic acid) scaffold with a nano-hydroxyapatite coating for the treatment of segmental bone defect in a rabbit model. Int. J. Nanomed. 2013, 8, 1855-1865. [CrossRef]

43. Li, T.-T.; Ling, L.; Lin, M.-C.; Jiang, Q.; Lin, J.-H.; Lin, J.-H.; Lou, C.-W. Properties and Mechanism of Hydroxyapatite Coating Prepared by Electrodeposition on a Braid for Biodegradable Bone Scaffolds. Nanomaterials 2019, 9, 679. [CrossRef] [PubMed]

44. Chai, Y.C.; Kerckhofs, G.; Roberts, H.C.; Van Bael, S.; Schepers, E.; Vleugels, J.; Luyten, F.P.; Schrooten, J. Ectopic bone formation by 3D porous calcium phosphate-Ti6Al4V hybrids produced by perfusion electrodeposition. Biomaterials 2012, 33, 4044-4058. [CrossRef] [PubMed]

45. Clara, S.; Rice, D.S.; Yamasani, A.; Jose, S.; Parks, J.B.; Clara, S.; Millar, E.; View, M.; Richardson, P.C. High Speed Three-Dimensional Weaving Method And Machine. U.S. Patent 6,315,007, 13 November 2001.

46. Mohamed, M.H.; Bogdanovich, A.E. Comparative Analysis of Different 3D Weaving Processes, Machines and Products. In Proceedings of the 17th International Confrence on Composite Materials, Edinburgh, UK, 27-31 July 2009.

47. Zhao, L.; Ha, S.; Sharp, K.W.; Geltmacher, A.B.; Fonda, R.W.; Kinsey, A.H.; Zhang, Y.; Ryan, S.M.; Erdeniz, D.; Dunand, D.C.; et al. Permeability measurements and modeling of topology-optimized metallic 3-D woven lattices. Acta Mater. 2014, 81, 326-336. [CrossRef]

48. Zhao, L.; Ryan, S.M.; Lin, S.; Xue, J.; Ha, S.; Igusa, T.; Sharp, K.W.; Guest, J.; Hemker, K.J.; Weihs, T.P. Combining a distributed flow manifold and $3 \mathrm{D}$ woven metallic lattices to enhance fluidic and thermal properties for heat transfer applications. Int. J. Heat Mass Transf. 2017, 108, 2169-2180. [CrossRef]

49. Ha, S.-H.; Lee, H.Y.; Hemker, K.J.; Guest, J. Topology Optimization of Three-Dimensional Woven Materials Using a Ground Structure Design Variable Representation. J. Mech. Des. 2019, 141, 061403. [CrossRef] 
50. Jones, A.C.; Arns, C.H.; Sheppard, A.P.; Hutmacher, D.W.; Milthorpe, B.K.; Knackstedt, M.A. Assessment of bone ingrowth into porous biomaterials using MICRO-CT. Biomaterials 2007, 28, 2491-2504. [CrossRef]

51. Karageorgiou, V.; Kaplan, D. Porosity of 3D biomaterial scaffolds and osteogenesis. Biomaterials 2005, 26, 5474-5491. [CrossRef]

52. Nyberg, E.; Farris, A.; O'Sullivan, A.; Rodriguez, R.; Grayson, W.L. Comparison of Stromal Vascular Fraction and Passaged Adipose-Derived Stromal/Stem Cells as Point-of-Care Agents for Bone Regeneration. Tissue Eng. Part A 2019, 25, 1459-1469. [CrossRef]

53. Rindone, A.N.; Nyberg, E.; Grayson, W.L. 3D-Printing Composite Polycaprolactone-Decellularized Bone Matrix Scaffolds for Bone Tissue Engineering Applications. Breast Cancer 2017, 30, 209-226.

54. Kuo, M.; Yen, S. The process of electrochemical deposited hydroxyapatite coatings on biomedical titanium at room temperature. Mater. Sci. Eng. C 2002, 20, 153-160. [CrossRef]

55. Park, J.-H.; Lee, D.-Y.; Oh, K.-T.; Lee, Y.-K.; Kim, K.-M.; Kim, K.-N. Bioactivity of calcium phosphate coatings prepared by electrodeposition in a modified simulated body fluid. Mater. Lett. 2006, 60, 2573-2577. [CrossRef]

56. Ogawa, T.; Yamada, M.; Ueno, T.; Tsukimura, N.; Ikeda, T.; Nakagawa, K.; Hori, N.; Suzuki, T. Bone integration capability of nanopolymorphic crystalline hydroxyapatite coated on titanium implants. Int. J. Nanomed. 2012, 7, 859-873. [CrossRef]

57. Wang, H.; Guan, S.-K.; Wang, X.; Ren, C.; Wang, L. In vitro degradation and mechanical integrity of Mg-Zn-Ca alloy coated with Ca-deficient hydroxyapatite by the pulse electrodeposition process. Acta Biomater. 2010, 6, 1743-1748. [CrossRef]

58. Koutsopoulos, S. Synthesis and characterization of hydroxyapatite crystals: A review study on the analytical methods. J. Biomed. Mater. Res. 2002, 62, 600-612. [CrossRef]

59. Tsuda, H.; Arends, J. Raman Spectra of Human Dental Calculus. J. Dent. Res. 1993, 72, 1609-1613. [CrossRef]

60. Wang, H.; Zhu, S.; Wang, L.; Feng, Y.; Ma, X.; Guan, S. Formation mechanism of Ca-deficient hydroxyapatite coating on Mg-Zn-Ca alloy for orthopaedic implant. Appl. Surf. Sci. 2014, 307, 92-100. [CrossRef]

61. Da Silva, M.P.; Lima, J.; Soares, G.; Elias, C.N.; de Andrade, M.; Best, S.; Gibson, I.; da Silva, M.H.P. Transformation of monetite to hydroxyapatite in bioactive coatings on titanium. Surf. Coat. Technol. 2001, 137, 270-276. [CrossRef]

62. Eliaz, N.; Sridhar, T.M. Electrocrystallization of Hydroxyapatite and Its Dependence on Solution Conditions. Cryst. Growth Des. 2008, 8, 3965-3977. [CrossRef]

63. Thanh, D.T.M.; Nam, P.T.; Phuong, N.T.; Que, L.X.; Van Anh, N.; Hoang, T.; Lam, T.D. Controlling the electrodeposition, morphology and structure of hydroxyapatite coating on 316L stainless steel. Mater. Sci. Eng. C 2013, 33, 2037-2045. [CrossRef] [PubMed]

64. Song, Y.; Zhang, S.; Li, J.; Zhao, C.; Zhang, X. Electrodeposition of Ca-P coatings on biodegradable Mg alloy: In vitro biomineralization behavior丸s. Acta Biomater. 2010, 6, 1736-1742. [CrossRef] [PubMed]

(C) 2020 by the authors. Licensee MDPI, Basel, Switzerland. This article is an open access article distributed under the terms and conditions of the Creative Commons Attribution (CC BY) license (http://creativecommons.org/licenses/by/4.0/). 